\title{
Identifikasi Tingkat Pemanfaatan Teknologi Fermentasi Jerami Padi Sebagai Pakan Alternatif Untuk Ternak Sapi Potong Di Kecamatan Lareh Sago Halaban
}

\author{
Yesi Chwenta Sari ${ }^{1 *}$, Syafri Nanda ${ }^{2}$ \\ ${ }^{1}$ Dosen Bagian Ilmu Nutrisi dan Teknologi Pakan, Fakultas Peternakan, Universitas Andalas \\ ${ }^{2}$ Dosen Bagian Teknologi dan Produksi Ternak, Fakultas Peternakan, Universitas Andalas \\ *Corresponding authors: yesichwentasari@ansci.unand.ac.id
}

\begin{abstract}
Abstrak
Permasalahan ketersediaan pakan saat musim kemarau dapat diatasi dengan cara memanfaatkan limbah-limbah pertanian seperti jerami padi yang sudah tidak terpakai dan jumlahnya sangat banyak untuk dijadikan pakan ternak, namun jerami padi memiliki kandungan nutrisi yang rendah sehingga diperlukan teknologi pegolahan pakan dengan cara fermentasi jerami padi. Penelitian ini bertujuan untuk mengidentifikasi tingkat pengetahuan peternak terhadap pemanfaatan teknologi fermentasi jerami padi sebagai pakan alternatif untuk ternak sapi potong di Kecamatan Lareh Sago Halaban Kabupaten Lima Puluh Kota Provinsi Sumatera Barat. Penelitian ini dilaksanakan dengan metode survey melalui wawancara melibatkan 60 orang peternak sebagai responden. Selain wawancara juga dilakukan pengamatan langsung di lapangan. Hasil penelitian menunjukkan bahwa tingkat pengetahuan peternak terhadap teknologi fermentasi jerami padi sebesar $63,3 \%$, dimana untuk tingkat pemahaman dan penerapan peternak terhadap teknologi fermentasi jerami padi diperoleh data sebagai berikut yaitu $15,8 \%$ paham dan diterapkan, $26,3 \%$ paham dan tidak diterapkan, serta $57,9 \%$ tidak paham dan tidak diterapkan. Informasi teknologi pengolahan pakan didapatkan peternak dari pelatihan sebesar $19,51 \%$, dari penyuluhan $34,2 \%$, dari media elektronik $39,1 \%$ dan dari buku 7,3\%. Dari hasil penelitian ini dapat disimpulkan bahwa pemanfaatan dan penerapan teknologi fermentasi jerami padi sebagai pakan alternatif ternak sapi potong oleh peternak di Kecamatan Lareh Sago Halaban masih dikategorikan rendah sebesar $(15,8 \%)$.
\end{abstract}

Kata Kunci: Teknologi pakan, Fermentasi jerami padi, Pakan alternatif, Sapi potong

\begin{abstract}
Farmers can overcome the problem of feed availability during the dry season by utilizing agricultural wastes such as unused rice straw and large quantities to be used as animal feed, but rice straw has low nutrient content, so it requires feed processing technology by fermentation rice straw. This study aims to identify farmers' knowledge of rice straw fermentation technology as an alternative feed for beef cattle in Lareh Sago Halaban District, Lima Puluh Kota Regency, West Sumatra Province. This research was conducted with a survey method through interviews involving 60 farmers as respondents. In addition to interviews, direct observation was also carried out in the field. The results showed that the level of farmers knowledge of rice straw fermentation technology was $63.3 \%$, where for the level of understanding and application of farmers to rice straw fermentation technology, the following data were obtained, namely $15.8 \%$ understood and applied, 26.3\% understood and did not applied, and 57.9\% did not understand and did not apply. Information on feed processing technology obtained by farmers from training was $19.51 \%$, from counseling $34.2 \%$, from electronic media $39.1 \%$, and from books $7.3 \%$. It can be concluded that the use and application of rice straw fermentation technology as an alternative feed for beef cattle by farmers in Lareh Sago Halaban District is still categorized as low (15.8\%).
\end{abstract}

Keywords: Feed technology, Rice straw Fermentation, Alternative feed, Beef cattle 
Prosiding Seminar Nasional Pembangunan dan Pendidikan Vokasi Pertanian

Politeknik Pembangunan Pertanian Manokwari, 14 November 2020

e ISSN : 2774-1982

\section{PENDAHULUAN}

Kabupaten lima puluh kota memiliki potensi yang sangat besar untuk pengembangan sapi potong, jumlah populasi ternak sapi terbanyak yaitu di Kecamatan Lareh Sago Halaban sebesar 10.190 ekor (BPS Kabupaten Lima Puluh Kota, 2020). Upaya untuk meningkatkan produktivitas ternak sapi potong terkendala karena masalah keterbatasan jumlah hijauan pakan ternak. Pakan adalah komponen terbesar dari total keseluruhan biaya pakan. Hampir 75\% dihabiskan untuk kebutuhan biaya pakan. Pakan ternak sangat berfluktuatif akan ketersediaanya. Ketika musim penghujan produksi hijauan sebagai pakan ternak sangat berlimpah, kondisi terbalik didapatkan pada saat musim kemarau panjang. Peternak kesulitan mendapatkan hijauan pakan untuk ternaknya. Sedangkan ternak harus diberikan pakan setiap hari untuk memenuhi kebutuhan hidup, produksi dan reproduksinya. Selain itu sebagian besar peternak memlihara sapi dengan pola sistem pemeliharaan yang sederhana sehingga tidak mampu memberikan pertumbuhan yang maksimal.

Di daerah tropis seperti wilayah di Indonesia, penyediaan bahan pakan ternak dalam jumlah dan kualitas yang cukup sepajang tahun kemungkinan sangat tipis sehingga untuk mempertahankan ketersediaan pakan terutama di musim kemarau perlu dicarikan solusi pakan alternatif. Salah satu pakan alternatif yang murah dan kompetitif adalah melalui pemanfaatan limbah, baik limbah pertanian, perkebunan, maupun agroindustri. Jerami padi merupakan salah satu limbah pertanian yang jumlahnya banyak di daerah Kabupaten Lima Puluh Kota karena sebagian besar penduduknya adalah petani yang menanam padi di sawah. Namun limbah jerami padi ini belum termanfaatkan dengan baik. Produksi jerami padi bisa mencapai 12-15 ton per ha/satu kali panen atau 4-5 ton bahan kering tergantung pada lokasi dan varietas yang digunakan (Yunilas, 2009).

Penggunaan jerami padi sebagai pakan ternak mempunyai beberapa kelemahan yaitu rendahnya kandungan nutrisi dan tingginya kandungan lignin dan silika. Selain itu kecernaan jerami padi juga rendah karena sulit didegradasi oleh mikroba rumen (Van Soest, 2006; Sarnklong et al., 2010). Kelemahan yang lainnya pada jerami padi yaitu palatablitasnya rendah (Tilman et al., 1998). Oleh karena itu perlu dilakukan teknologi pengolahan pakan yang bersifat praktis dan ekonomis supaya mudah dilakukan bagi peternakan rakyat. Beberapa penelitian tentang inovasi teknologi yang terkait dengan pemanfaatan jerami padi sebagai sumber pakan berserat bagi ternak ruminansia sudah banyak dilaporkan (Kargbo et al., 2009). Sampai saat ini metode yang paling banyak digunakan untuk meningkatkan nilai nutrisi limbah jerami padi adalah dengan perlakuan 
Prosiding Seminar Nasional Pembangunan dan Pendidikan Vokasi Pertanian Politeknik Pembangunan Pertanian Manokwari, 14 November 2020

e ISSN : 2774-1982

fisik (Missotten et al., 2010), perlakuan secara kimiawi (Ismail et al., 2012), dan perlakuan biologis (Wang et al., 2016). Metode biologis dan kimia merupakan pilhan metode yang paling sering digunakan (Van Soest, 2006). Teknologi fermentasi jerami padi adalah salah satu teknologi pengolahan limbah jerami padi untuk pakan alternatif ternak sapi potong. Teknologi ini bersifat sederhana, murah, dan mudah untuk diaplikasikan oleh peternak. Tujuan dari penelitian ini yaitu untuk mengidentifikasi tingkat pengetahuan peternak terhadap pemanfaatan teknologi fermentasi jerami padi sebagai pakan alternatif untuk ternak sapi potong di Kecamatan Lareh Sago Halaban Kabupaten Lima Puluh Kota Provinsi Sumatera Barat.

\section{METODE}

Penelitian dilaksanakan di Kecamatan Lareh Sago Halaban, Kabupaten Lima Puluh Kota, Provinsi Sumatera Barat. Kecamatan Lareh Sago Halaban dipilih secara purposive sampling dengan mempertimbangkan jumlah populasi ternak sapi potong. Penelitian dilaksanakan pada bulan September-Oktober 2020 menggunakan metode survey melalui wawancara melibatkan 60 orang peternak sebagai responden. Responden dipilih dari 3 Nagari/Desa yang merupakan sentra populasi sapi potong di Kecamatan Lareh Sago Halaban yaitu Nagari/Desa Labuah Gunuang, Nagari/Desa Balai Panjang, Nagari/Desa Batu Payuang.

Pengumpulan data dalam penelitian ini bersumber dari data primer dan data sekunder. Data primer berasal dari hasil wawancara dengan peternak. Selain wawancara juga dilakukan observasi atau pengamatan langsung terhadap fenomena yang akan dikaji, dalam hal ini peneliti terjun langsung ke lapangan dalam lingkungan peternak. Menurut Arikunto (2006), observasi adalah pengamatan dan pengumpulan data yang dilakukan dengan cara mengamati dan mencatat segala peristiwa secara sistematis terhadap objek yang diselidiki. Observasi digunakan untuk mendapatkan gambaran nyata di lapangan.

\section{HASIL DAN PEMBAHASAN}

\section{Profil Wilayah dan Pembangunan Peternakan di Kabupaten Lima Puluh Kota}

Kabupaten Lima Puluh Kota mempunyai luas wilayah $3.354,30 \mathrm{~km}^{2}$ (BPS Kabupaten Lima Puluh Kota, 2020). Kabupaten Lima Puluh Kota mempunyai potensi besar untuk usaha sapi potong. Jumlah populasi sapi di Kabupaten Lima Puluh Kota yaitu 42.747 ekor. Keadaan populasi ternak di Kabupaten Lima Puluh Kota pada tahun 2019 terlihat pada Tabel 1. 
Prosiding Seminar Nasional Pembangunan dan Pendidikan Vokasi Pertanian

Politeknik Pembangunan Pertanian Manokwari, 14 November 2020

e ISSN : 2774-1982

Tabel 1. Populasi Ternak Menurut Jenis dan Kecamatan di Kabupaten Lima Puluh Kota

\begin{tabular}{lcccc}
\hline \multirow{2}{*}{ Kecamatan } & \multicolumn{4}{c}{ Jenis Ternak } \\
\cline { 2 - 5 } & Kuda & Kambing & Sapi & Kerbau \\
\hline Payakumbuh & 4 & 2.601 & 2.352 & 921 \\
Akabiluru & 14 & 2.015 & 1.954 & 1.862 \\
Luak & 7 & 2.872 & 8.725 & 925 \\
Lareh Sago Halaban & - & 4.550 & 10.190 & 1.776 \\
Situjuah Lima Nagari & 10 & 2.217 & 4.013 & 1.322 \\
Harau & 37 & 3.578 & 5.851 & 859 \\
Guguak & 6 & 1.024 & 4.035 & 329 \\
Mungka & 13 & 2.814 & 1.162 & 261 \\
Suliki & 4 & 1.108 & 645 & 786 \\
Bukik Barisan & - & 4.406 & 2.606 & 1.106 \\
Gunuang Omeh & - & 981 & 327 & 650 \\
Kapur IX & - & 1.110 & 285 & 833 \\
Pangkalan Kota Baru & - & 1.037 & 602 & 699 \\
\hline Jumlah & 95 & 30.313 & 42.747 & 12.329 \\
\hline
\end{tabular}

Sumber: BPS Kabupaten Lima Puluh Kota, 2020.

Berdasarkan Tabel 1 terlihat bahwa ternak sapi merupakan komoditas terbesar di Kabupaten Lima Puluh Kota dengan sentra populasi ternak sapi yaitu di Kecamatan Lareh Sago Halaban sebanyak 10.190 ekor. Sedangkan untuk Nagari/Desa yang paling banyak ternak sapi di Kecamatan Lareh Sago Halaban disajikan pada Tabel 2.

Tabel 2. Populasi Ternak Besar dan Kecil Menurut Nagari/Desa di Kecamatan Lareh Sago Halaban

\begin{tabular}{lcccc}
\hline \multirow{2}{*}{ Nagari } & \multicolumn{4}{c}{ Jenis Ternak } \\
\cline { 2 - 5 } \multicolumn{1}{c}{ Kuda } & Kerbau & Sapi & Kambing \\
\hline Bukik Sikumpa & - & 124 & 1.202 & 141 \\
Balai Panjang & - & 346 & 1.678 & 882 \\
Batu Payuang & - & 251 & 1.551 & 415 \\
Labuah Gunuang & - & 203 & 1.771 & 816 \\
Tanjuang Gadang & - & 300 & 815 & 451 \\
Sitanang & - & 171 & 842 & 565 \\
Halaban & - & 180 & 1.008 & 298 \\
Ampalu & - & 72 & 772 & 366 \\
\hline Jumlah & - & 1.647 & 9.639 & 3.934 \\
\hline
\end{tabular}

Sumber : BPS Kecamatan Lareh Sago Halaban, 2019.

Berdasarkan Tabel 2 terlihat bahwa tiga Nagari paling banyak populasi ternak sapinya yaitu Nagari Labuah Gunuang sebesar 1.771 ekor, kemudian Nagari Balai Panjang sebesar 1.678 ekor, dan selanjutnya Nagari Batu Payuang sebesar 1.551 ekor ternak sapi. 
Prosiding Seminar Nasional Pembangunan dan Pendidikan Vokasi Pertanian

Politeknik Pembangunan Pertanian Manokwari, 14 November 2020

e ISSN : 2774-1982

\section{Pengetahuan Peternak di Kecamatan Lareh Sago Halaban Terhadap Teknologi Pengolahan Pakan}

Tabel 3. Tingkat Pengetahuan Peternak Terhadap Teknologi Pengolahan Pakan

\begin{tabular}{lcc}
\hline \multicolumn{1}{c}{ Tingkat Pengetahuan Peternak } & $\begin{array}{c}\text { Jumlah Responden } \\
\text { (orang) }\end{array}$ & Persentase (\%) \\
\hline Mengetahui & 41 & 68,3 \\
Tidak Mengetahui & 19 & 31,7 \\
\hline
\end{tabular}

Berdasarkan hasil penelitian yang disajikan pada Tabel 3 menunjukkan bahwa pengetahuan peternak terkait teknologi pengolahan pakan pada umumnya sudah mengetahui. Sebanyak 68,3\% responden mengetahui teknologi pengolahan pakan dan selebihnya $31,7 \%$ responden tidak mengetahui teknologi pengolahan pakan. Dari hasil survey diketahui bahwa peternak kebanyakan merupakan dari generasi tua dan sedikit dari generasi muda. Faktor umur memiliki keterkaitan dengan semangat dan produktivitas kerja. Chamdi (2003) menyatakan semakin muda peternak (usia produktif) maka tingkat keingintahuannya terhadap sesuatu semakin tinggi dan minat untuk menerapkan teknologi semakin tinggi. Selain faktor umur, faktor lain yang cukup memberikan pengaruh yaitu tingkat pendidikan peternak. kebanyakan dari responden memiliki tingkat pendidikan SD dan tidak tamat SD sehingga sulit untuk mengembangkan usaha peternakannya. Usaha beternak sapi dilakukan secara turun temurun dan merupakan usaha sampingan, serta hampir semua responden mempunyai pengalaman beternak sapi lebih dari 10-15 tahun.

Tabel 4. Jenis Teknologi Pakan

\begin{tabular}{lcc}
\hline Teknologi Pakan yang Diketahui & Jumlah Responden (orang) & Persentase (\%) \\
\hline Fermentasi Jerami Padi & 38 & 63,3 \\
Amoniasi & 10 & 16,7 \\
Hay & 0 & 0 \\
Silase & 5 & 8,3 \\
Pencacahan/Pemotongan & 41 & 68,3 \\
UMB & 0 & 0 \\
Wafer Pakan & 0 & 0 \\
\hline
\end{tabular}

Berdasarkan hasil penelitian yang disajikan pada Tabel 4 bahwa jenis teknologi pakan yang diketahui oleh peternak yaitu teknologi fermentasi jerami padi sebanyak 
Prosiding Seminar Nasional Pembangunan dan Pendidikan Vokasi Pertanian Politeknik Pembangunan Pertanian Manokwari, 14 November 2020

e ISSN : 2774-1982

$63,3 \%$ responden yang mengetahui, teknologi amoniasi $16,7 \%$, teknologi hay $0 \%$, teknologi silase 8,3\%, teknologi pencacahan/pemotongan 68,3\%, teknologi Urea Molasses Blok $(U M B)$ 0\%, dan teknologi wafer pakan 0\%. Teknologi pakan yang paling banyak diketahui peternak adalah pencacahan/pemotongan 68,3\% dan fermentasi jerami padi $63,3 \%$. Hal ini menggambarkan bahwa pengetahuan peternak terhadap teknologi pencacahan dan fermentasi jerami padi cukup tinggi. Tingginya jumlah peternak yang mengetahui teknologi pencacahan bahan pakan dan fermentasi jerami padi disebabkan peternak pernah mendapakan penyuluhan terkait fermentasi jerami sekitar 5 tahun yang lalu dan setelah itu belum ada dilakukan lagi penyuluhan terkait teknologi pengolahan pakan ternak. Sedangkan untuk teknologi pencacahan mudah untuk diterapkan, tidak rumit, dan tidak membutuhkan biaya.

Tabel 5. Tingkat Pemahaman Peternak Terhadap Teknologi Fermentasi Jerami Padi

\begin{tabular}{lccc}
\hline $\begin{array}{c}\text { Teknologi Fermentasi } \\
\text { Jerami Padi }\end{array}$ & Paham dan diterapkan & $\begin{array}{c}\text { Paham dan tidak } \\
\text { diterapkan }\end{array}$ & $\begin{array}{c}\text { Tidak paham } \\
\text { dan tidak } \\
\text { diterapkan }\end{array}$ \\
\hline Jumlah Responden & 6 & 10 & 22 \\
Persentase (\%) & 15,8 & 26,3 & 57,9 \\
\hline
\end{tabular}

Berdasarkan Tabel 5 terlihat bahwa tingkat pemahaman peternak terhadap teknologi fermentasi jerami padi yaitu $15,8 \%$ peternak paham dan menerapkan, 26,3\% paham akan tetapi tidak menerapkan di lapangan, dan 57,9\% tidak paham dan tidak diterapkan. Hal ini dikarenakan peternak tidak memahami cara membuat fermentasi jerami padi sebagai pakan alternatif bagi ternak, akan tetapi peternak pernah mendengar ketika mendapatkan penyuluhan terkait teknologi fermentasi jerami padi, namun karena tidak dilakukan pendampingan secara berkala sehingga peternak menjadi lupa dan tidak mengetahui lagi bagaimana cara mengolah pakan ternak dengan memanfaatkan limbah pertanian yang ada disekitarnya contohnya jerami padi yang jumlahnya berlimpah, dan mudah didapatkan. 


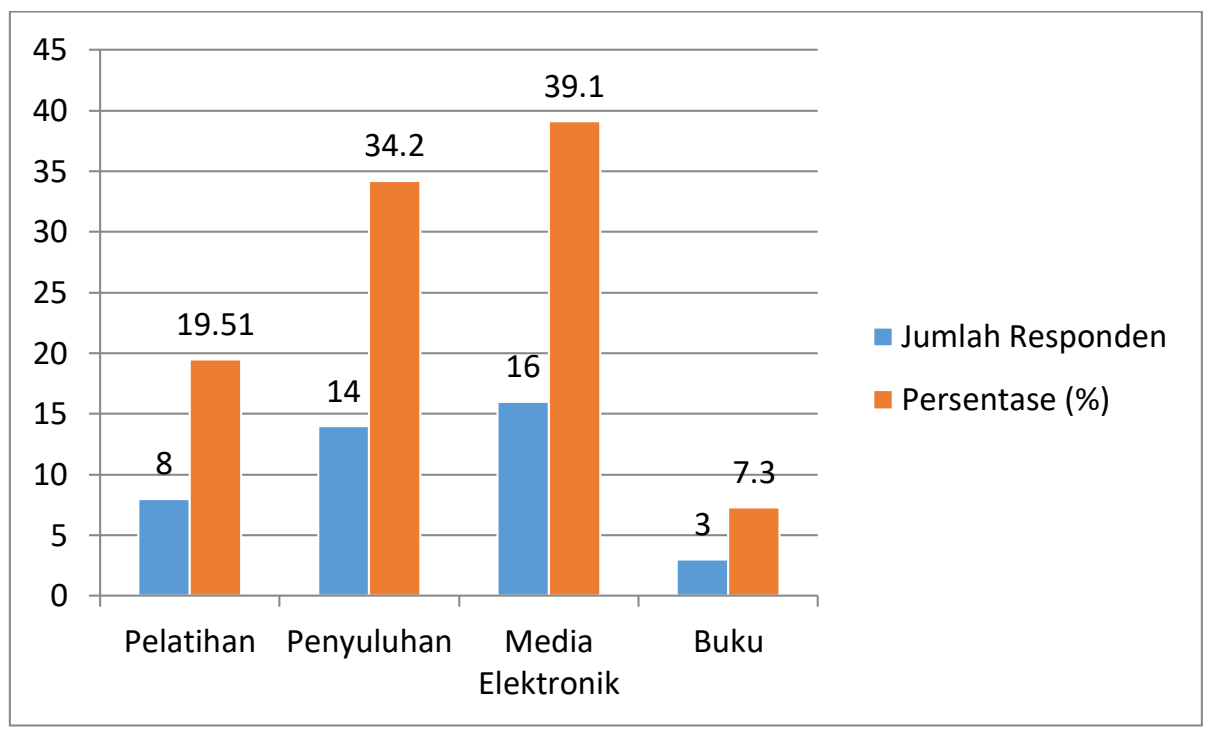

Gambar 1. Sumber Pengetahuan Peternak Terhadap Teknologi Fermentasi Jerami Padi

Sumber pengetahuan peternak paling banyak didapatkan melalui media elektronik seperti youtube, televisi, dan informasi via whatsapp sebesar $39,1 \%$, selain itu juga peternak mendapatkan informasi pengolahan pakan dari penyuluhan sebesar 34,2\%, kemudian dari pelatihan sebesar $19,51 \%$ dan dari buku 7,3\%. Meskipun informasi teknologi pengolahan pakan paling banyak didapatkan melalui media elektronik namun peternak tetap kesulitan menerapkannya karena hanya menonton tanpa praktek. Hal ini berbeda apabila peternak didampingi oleh penyuluh, peternak bisa berkomunikasi langsung dan bertanya serta tukar pendapat dengan penyuluh terkait permasalahan yang sedang dialami oleh peternak. Ada komunikasi timbal balik apabila diadakan penyuluhan langsung kepada peternak.

Peternak sangat membutuhkan informasi tentang teknologi pengolahan pakan yang sumber bahan bakunya banyak tersedia, mudah didapatkan, murah dari segi biaya, dan mudah pengaplikasiannya. Berdasarkan hasil wawancara kepada peternak maka didapatkan hasil bahwa peternak belum lagi mendapatkan penyuluhan dan pelatihan terkait teknologi pengolahan pakan. Penyuluhan terakhir diadakan sekitar 5 tahun yang lalu sedangkan peternak yang baru berternak kurang dari 5 tahun belum ada mendapatkan penyuluhan terkait teknologi pengolahan pakan. Oleh karena itu pentingnya diadakan penyuluhan terkait teknologi pengolahan pakan bagi peternak di Kecamatan Lareh Sago Halaban, terutama di tiga Nagari yang merupakan sentra jumlah populasi sapi terbanyak yaitu Nagari Labuah Gunuang, Nagari Balai Panjang, dan Nagari Batu Payuang. 
Prosiding Seminar Nasional Pembangunan dan Pendidikan Vokasi Pertanian

Politeknik Pembangunan Pertanian Manokwari, 14 November 2020

e ISSN : 2774-1982

\section{KESIMPULAN DAN SARAN}

Kesimpulan dari hasil penelitan ini adalah secara umum peternak telah mengetahui teknologi pengolahan pakan, namun untuk tingkat pemanfaatan dan penerapan teknologi fermentasi jerami padi sebagai pakan alternatif ternak sapi potong oleh peternak di Kecamatan Lareh Sago Halaban masih dikategorikan rendah sebesar $(15,8 \%)$. Hal ini disebabkan informasi yang dibutuhkan peternak tentang teknologi pakan tidak disediakan di lingkungan peternak. Jenis teknologi pakan yang diketahui dan diterapkan sebagian besar oleh peternak adalah pencacahan/pemotongan karena mudah dilakukan dan tidak membutuhkan biaya. Teknologi pencacahan/pemotongan pakan tidak meningkatkan kandungan nutrisi dari bahan pakan. Teknologi pencacahan pakan memiliki manfaat yaitu memperluas permukaan bahan pakan sehingga memungkinkan bakteri menembus lapisan pelindung dinding sel dan memperbanyak titik penetrasi enzim agar mudah dicerna. Saran dari penelitian ini adalah perlu dilakukan penyuluhan dan pendampingan oleh tim penyuluh dan tim akademisi Perguruan Tinggi untuk membantu peternak dalam mengatasi permasalahan ketersediaan pakan dengan menerapkan teknologi pengolahan pakan yang murah dari segi biaya, mudah dipelajari dan diterapkan, dengan pemanfaatan berbasis limbah-limbah pertanian dan perkebunan yang ada di sekitar lingkungan peternak.

\section{DAFTAR PUSTAKA}

Arikunto, S. (2006). Metode Penelitian Kualitatif. Jakarta: Bumi Aksara.

Badan Pusat Statistik Kabupaten Lima Puluh Kota. (2020). Kabupaten Lima Puluh Kota Dalam Angka 2020.

Badan Pusat Statistik Kecamatan Lareh Sago Halaban. (2019). Kecamatan Lareh Sago Halaban Dalam Angka 2019.

Chamdi, A.N. (2003). Kajian Profil Sosial Ekonomi Usaha Kambing Di Kecamatan Kradenan Kabupaten Grobongan. Pros. Seminar Nasional Teknologi Peternakan dan Veteriner. Bogor, 29-30 September 2003. Puslitbang Peternakan, Bogor. Hal 312-317.

Ismail, M. Abd El Razik, G.A Abd Elrahman \& M.S Ayyat. (2012). Effect of Biological And Chemical Treatments of Rice Straw On Lamb Performance. Zagazing J. Agric. Res. 39 (4): 655-664.

Kargbo, F.R., \& J. Xingand Y. Zhang. (2009). Preteartment for Energy Use of Rice Straw: A Review. African Journal of Agricultural Research. 4(12): 1-6.

Missotten, J.A.M., J. Michiels, A. Ovyn, S. De Smet \& N.A Dierick. (2010). Fermented Liquid Feed for Pigs. Arch Anim Nutr. 
Sarnklong, C., J. W. Cone, W. Pellikaan \& W.H. Hendriks. (2010). Utilization of Rice Straw and Different Treatments to Improve Its Feed Value for Ruminants: A Review. Asian-Aust. J.Anim. Sci. 23 (5): 680-692.

Tilman, D.A., Hartadi, H. Reksohadiprodjo, S., \& lebdosoekojo, S. (1998). Ilmu Makanan Ternak Dasar. Gadjah Mada University Press, Yogyakarta.

Van Soest, P.J. (2006). Rice Straw, The Role of Silica and Treatments to Improve Quality. Anim Feed Sci Technol 130 (3-4): 137-171.

Wang, Y.S., W.Shi, L.T. Huang, C.L. Ding \& C.C. Dai. (2016). The Effect of Lactic Acid Bacterial Starter Culture and Chemical Additives on Wilted Rice Straw Silage. Animal Science Journal 187(4):525-535.

Yunilas. (2009). Karya Ilmiah. Bioteknologi Jerami Padi Melalui Fermentasi sebagai Bahan Pakan Ternak Ruminansia. Fakultas Pertanian, Universitas Sumatera Utara, Medan. 